\title{
1. Central issues in the protection of child migrants
}

\section{Mary Crock and Lenni B. Benson}

\section{SEEING AND HEARING THE MIGRANT CHILD}

In September 2015, images of a three-year-old Syrian child washed ashore on Turkey's Aegean coast dominated media around the world. Aylan Kurdi's tiny, lifeless body was photographed face down on the water's edge; watched by solemn-looking Turkish policemen; lifted and carried gently to dry land. Returning to the village from which the family had fled, the grieving father buried the toddler along with the child's mother and older brother. ${ }^{1}$ These children became the faces of the tragedy unfolding in Syria. Their deaths brought home the dangers and human cost of the mass forced migration sweeping across Europe. Yet the tragedies continue. As this book was going to press, thousands of Rohingyan refugees were fleeing religious, ethnic and political violence in Myanmar. Between August and October 2017, the United Nation's International Children's Emergency Fund (UNICEF) estimated that 230,000 Rohingyan children had crossed the border into Bangladesh. Unable to secure work and legal status, many of these children were immediately vulnerable to trafficking and slavery. ${ }^{2}$

We write at a time of relentless change, if not crisis. In the West, long-standing cooperative frameworks of the European Union (EU) are threatened with disintegration after Britain's decision to withdraw from the Union. ${ }^{3}$ Minority communities in the United States of America (US)

1 See, e.g., H. Smith, 'Shocking images of drowned Syrian boy show tragic plight of refugees', The Guardian (online), 2 September 2015, available at www.the guardian.com/world/2015/sep/02/shocking-image-of-drowned-syrian-boy-shows -tragic-plight-of-refugees.

2 UNICEF, Outcast and Desperate: Rohingya Refugee Children Face a Perilous Future (UNICEF, October 2017) available at www.unicef.org/publications/files/ UNICEF_Rohingya_refugee_children_2017.pdf.

3 See, e.g., the collection of articles published in The Economist, available at www.economist.com/Brexit. 
have been unsettled by sweeping anti-immigrant Executive Orders and other measures following the election of President Donald Trump. ${ }^{4}$ For its part, the EU has put unprecedented pressure on an external state, Turkey, to accept the return of people seeking protection in EU countries. Already playing host to millions of refugees from the Syrian conflict, an attempted coup in that country prompted dangerously repressive measures from President Recep Tayyip Ergodan. ${ }^{5}$ The threat of terrorism seemed to spread even as the 'Caliphate' of fundamentalist groups such as the Islamic State (Isis or Daesh) diminished. ${ }^{6}$ Candidates with increasingly extreme (often xenophobic) views have been elected or nominated for high office across the world. ${ }^{7}$

In many instances, political movements to the right appear to have roots in public concern about (uncontrolled) migration. ${ }^{8}$ The percentage of people on the move around the world may have remained relatively stable (at 3.3 per cent of the world's population). ${ }^{9}$ However, numbers

4 For a collection of the Executive Orders restricting the admission of refugees and cancelling some of the special programmes for resettlement of children in the United States see, generally, https://pennstatelaw.psu.edu/immigration-after -election.

5 See, e.g., E. Cunningham, L. Sly and Z. Karatas, 'Turkey rounds up thousands of suspects in failed coup attempt', Washington Post, 16 July 2016, available at www.washingtonpost.com/world/after-bloody-night-turkeys-president-declarescoup-attempt-foiled/2016/07/16/9b84151e-4af7-11e6-8dac-0c6e4accc5b1_story. html.

6 See, e.g., K. Yourish, D. Watkins, T. Guratikanon and J.C. Lee, 'How many people have been killed in ISIS attacks around the world?', New York Times, 16 July 2016, available at www.nytimes.com/interactive/2016/03/25/world/map-isisattacks-around-the-world.html?_r=0.

7 Examples in 2016 include: Norbert Hofer won 47.6 per cent of the vote in Austria and narrowly lost the national election after running on a nationalist and anti-immigrant platform. Donald Trump won the US Presidency after promising mass deportations and tough new border controls. Pauline Hanson and three other members of an extreme right wing anti-immigrant party, One Nation, were elected to the Australian Senate. See the collection of articles at www.theguardian.com/ world/far-right. See also M. Hirsch, 'Why the New Nationalists are Taking Over', Politico, 27 June 2016, available at www.politico.com/magazine/story/2016/06/ nationalism-donald-trump-boris-johnson-brexit-foreign-policy-xenophobiaisolationism-213995.

8 See, e.g., S. Collinson and J. Diamond, 'Trump on immigration: no amnesty, no pivot', CNN, 1 September 2016, available at http://edition.cnn.com/2016/08/31/ politics/donald-trump-immigration-speech/ and A. Travis, 'Fear of immigration drove the leave victory - not immigration itself', The Guardian (online), 24 June 2016, available at www.theguardian.com/politics/2016/jun/24/voting-details-show -immigration-fears-were-paradoxical-but-decisive.

9 See UN Department of Economic and Social Affairs (DESA), International 
migrating to developed countries have risen sharply in recent decades. If forced migration between developing and developed countries has become one of the world's great problems, the movement of children as migrants represents compounding complexity. By the start of 2017 it was estimated that nearly 51 per cent of the world's 65.6 million forcibly displaced people were children and that approximately 22.5 million were in need of humanitarian protection. ${ }^{10}$ Using UN data, UNICEF claims that one in 200 children in the world was a child refugee in 2015, representing a doubling of the global population of such children in one decade. ${ }^{11}$ In some instances, the rise in the number of children travelling alone has been so extreme that systems are overwhelmed, eroding support for the protection of these most vulnerable of migrants. ${ }^{12}$

After years of uncertainty and mass international movements of children, the United Nations (UN) has begun to address the need for express

Migration Report 2015 (September 2016), available at www.un.org/en/development/ desa/population/migration/index.shtml.

10 UNHCR, Global Trends: Forced Displacement in 2016 (December 2016), available at www.unhcr.org/5943e8a34.pdf. These estimates exceed the mid-year all-time high, see A. Edwards, Global Forced Migration Hits Record High (UNHCR, 20 June 2016), available at www.unhcr.org/en-us/news/latest/2016/6/5763b65a4/ global-forced-displacement-hits-record-high.html.

11 See, e.g., UNICEF, Uprooted: The Growing Crisis for Refugee and Migrant Children (7 September 2016), available at http://weshare.unicef.org/ Package/2AMZIFQP5K8. In 2017, UNICEF and IOM estimated that 100,000 children under the age of 18 had crossed into Europe since 2016 and that over 20 per cent of those who sought asylum were unaccompanied. See UNICEF and IOM, Harrowing Journeys: Children and Youth on the Move Across the Mediterranean Sea, at Risk of Trafficking and Exploitation (2017), p. 31, available at www.unicef. org/publications/files/Harrowing_Journeys_Children_and_youth_on_the_move_ across_the_Mediterranean.pdf. For a discussion of the statistical data, see Arezo Mallakooti, Chapter 2.

12 In 2017, the United Kingdom was thought to host as many as 65,000 unaccompanied migrant children whose right to remain would be contested as they reached their 18th birthday (the age of legal majority in that country). See Law Society of Scotland, 'Legal Services Agency Co-Founds Migrant Children Project', The Journal, 24 May 2016, available at www.journalonline.co.uk/News/1021800. aspx\#.V8oiNJgrKM8. One Interpol report suggests that in 2015-16 one in every nine unaccompanied children was unaccounted for in Europe. See UNICEF Press Release, Unaccompanied Refugee and Migrant Children in Urgent Need of Protection, Warns UNICEF (6 May 2016), available at www.unicef.org/media/ media_91069.html. With its extensive undocumented population, the United States also plays host to very large numbers of undocumented migrant children. A 2014 survey estimated that there were 1.4 million people under 21 years of age, of an estimated 11 million undocumented migrants. See American Community Survey 2014 data available at http://cmsny.org/cms-research/democratizingdata/. 
principles that will guide and govern the treatment of children on the move. In September 2016, on the eve of his departure from US political life, President Barack Obama hosted a leaders' Summit on Refugees, an event that paralleled the High Level Summit organized by the UN General Assembly on the large-scale movement of refugees and migrants. ${ }^{13}$ The resulting New York Declaration for Refugees and Migrants, adopted unanimously by UN member states, has been described as 'a milestone for global solidarity with refugees and the global refugee regime'. ${ }^{14}$ The Declaration is in three parts, beginning with a section that applies to both migrants and refugees, followed by two parts relating separately to refugees and to migrants. One of the most significant aspects of the instrument is that for the first time UN member states committed to sharing responsibility for refugees. It reads:

We underline the centrality of international cooperation to the refugee protection regime. We recognize the burdens that large movements of refugees place on national resources, especially in the case of developing countries. To address the needs of refugees and receiving States, we commit to a more equitable sharing of the burden and responsibility for hosting and supporting the world's refugees, while taking account of existing contributions and the differing capacities and resources among States. ${ }^{15}$

The Declaration includes two important appendices: Annex I, the 'Comprehensive Refugee Response Framework', and Annex II, entitled 'Towards a Global Compact for Safe, Orderly and Regular Migration'. These contain the elements of frameworks for a comprehensive 'people centred' response to the challenges of forced and mass migration. They task UNHCR and the International Organisation for Migration (IOM) with initiating the application of the agreed frameworks through the conclusion of two 'Global Compacts'. The objective of the Compacts is to improve international responses to large movements of refugees and migrants, including protracted refugee situations. They are to be included in the Secretary General's 2018 Annual Report to the UN General Assembly.

The period following the New York Declaration saw a flurry of activity as UNHCR and IOM worked together and separately to convene a whole range of meetings - thematic, regional, academic, 'stakeholder',

\footnotetext{
13 See http://refugeesmigrants.un.org/summit.

14 UNHCR, 'Towards a Global Compact on Refugees: A Roadmap', available at www.unhcr.org/58e625aa7.

15 New York Declaration for Refugees and Migrants, 3 October 2016, para. [68], available at www.un.org/en/ga/search/view_doc.asp?symbol=A/RES/71/1.
} 
'stocktaking', all with a focus on a 2018 deadline. For us, these initiatives give reason for at least cautious optimism. In mid-December 2017, President Trump made a show of declaring that the United States would play no part in the Global Compact on migrants. ${ }^{16}$ However, no mention was made of the process relating to refugees, which suggests that the United States may continue its involvement in this facet of the Global Compact process. If they are concluded, the two Compacts will be extraordinary achievements. However, even if this is not the case, the very process associated with their negotiation has worked to generate a sense of energy and enthusiasm for cooperation and change. Across Africa and parts of the Americas, a number of countries moved immediately to adopt the Comprehensive Refugee Response Framework (CRRF). ${ }^{17}$

As many have noted, the Global Compacts will be political instruments, rather than documents that directly bind states. In the recent past, the device of a 'Compact' was used to frame a multilateral agreement to compensate states hosting refugees from Syria on the understanding that the host states would impede or discourage onward movements (notably to Europe). ${ }^{18}$ The Global Compacts will be less specific in application and proscriptions. Their significance lies in the fact that they build on existing legal frameworks, including the 1951 Refugee Convention and the various UN human rights instruments. For international migrants, the Compact

16 Secretary of State Tillerson claimed that the gesture was necessary to affirm US state sovereignty. He rejected assertions that international cooperation was the best means to address large migration flows, including those of children. See www. state.gov/secretary/remarks/2017/12/276190.htm. See also R. Gladstone, 'US quits Migration Pact, saying it infringes on sovereignty', New York Times, 3 December 2017, available at www.nytimes.com/2017/12/03/world/americas/united-nationsmigration-pact.html?_r=0.

17 See, e.g., D. Endres, 'Update on the Practical Roll-out of the CRRF', Address at the Annual NGO Consultations, UNHCR, 14 June 2017, available at www.unhcr.org/en-us/594248734. The CRRF has four key aims: (1) ease pressure on countries that welcome and host refugees; (2) build self-reliance of refugees; (3) expand access to resettlement in third countries/other complementary pathways; (4) foster conditions that enable refugees voluntarily to return to their home countries. By December 2017, there had been agreed adoption of the framework in Djibouti, Ethiopia, Kenya, Uganda, Tanzania, Zambia, and Somalia. Belize, Costa Rica, Guatemala, Honduras, Mexico and Panama were taking similar steps.

18 See, e.g., Government of Jordan, 'The Jordan Compact: A New Holistic Approach between the Hashemite Kingdom of Jordan and the International Community to Deal with the Syrian Refugee Crisis', ReliefWeb, 7 February 2016, available at https://reliefweb.int/report/jordan/jordan-compact-new-holisticapproach-between-hashemite-kingdom-jordan-and; and EU-Lebanon Partnership, The Compact (European Commission, August 2017), available at https://ec.europa. eu/neighbourhood-enlargement/sites/near/files/lebanon-compact.pdf. 
has the potential to act as a real agent for change, if only because of the paucity of the legal frameworks that exist for the governance of migration outside of the refugee context. ${ }^{19}$ For present purposes, it is noteworthy that the undertakings of the states include a statement that they commit to:

protect the human rights and fundamental freedoms of all refugee and migrant children, regardless of their status, and giving primary consideration at all times to the best interests of the child, and to comply with their obligations under the Convention on the Rights of the Child. ${ }^{20}$

Of course, there are limitations inherent in the Global Compact process. Perhaps most disappointing is the decision to treat separately the issue of refugees and forced migration on the one hand and migration generally on the other. This decision will entrench the tendency to 'silo' law and practice in two areas that in reality are intrinsically linked. The complexity of refugee status determination processes everywhere reflects the fact that most mass migration events tend to involve mixed populations of both migrants and refugees. Moreover, the Compacts also exclude internally displaced persons (IDPs) who can be just as vulnerable (and as numerous) in displacement as refugees and international migrants. The side-events organized by UNICEF and specialist non-governmental organizations (NGOs) around the Global Compacts process underscore the fact that effort and organization continue to be required if the voices of children and of other vulnerable migrants are to be heard. The inclusion of these voices is critical if the Compacts are to achieve their full potential.

On 17 November 2017, two of the UN human rights treaty bodies issued Joint General Comments that address directly the protection needs of child migrants and refugees. ${ }^{21}$ The two comments outline key concerns

19 This point is made by T. Gammeltoft Hansen et al., 'The Normative Impact of the Global Compact on Safe, Orderly and Regular Migration' in What is a Compact? Migrants' Rights and State Responsibilities Regarding the Design of the UN Global Compact for Safe, Orderly and Regular Migration (Raoul Wallenberg Institute, 11 October 2017), available at https://papers.ssrn.com/sol3/papers. cfm?abstract_id=3051027. See also the other papers from the conference held by the Raoul Wallenberg Institute in October 2017; and E. Ferris, 'Negotiating Two New Global Compacts: Processes, Politics and Problems', Kaldor Centre Conference 2017, available at www.kaldorcentre.unsw.edu.au/kaldor-centre-confer ence-2017-global-compacts-refugees-and-migration.

20 General Assembly Resolution 71/1, para. [32].

21 Joint General Comment No. 3 (2017) of the Committee on the Protection of the Rights of All Migrant Workers and Members of Their Families and No. 
and articulate minimum protections essential for the health and safety of these children. At last, the international community seems to be recognizing the wisdom in demanding that member states adapt their procedures and substantive protections to recognize the unique challenges facing young migrants, particularly when travelling alone.

Around the globe children are migrating with and without their families in search of freedom, safety or simply a better life. They travel for education, for work, for pleasure, or for a complex combination of reasons. This book has at its centre the millions of children who are being or who have been displaced across borders by wars and other catastrophes. However, our collective concern is not just with these most vulnerable of children, but also with other young migrants whose experiences and needs are more finely nuanced.

We agree with the criticism advanced by UNICEF that child migrants are presented in the literature too frequently as 'passive, vulnerable and exploited'. ${ }^{22}$ At one extreme there are children who are subjected to human trafficking, a modern version of slavery. ${ }^{23}$ On the other hand, an increasing number of children travel abroad in situations of relative freedom in search of work or for other, facially benign reasons. As explored in the concluding parts of the book, stories of child migration can also involve threat and danger to receiving countries. Child soldiers are one iteration of children viewed by societies as a menace. Young people fleeing gang violence are perceived as another threat by some receiving communities. The growth of the smuggling industry is fuelled in part by child labour as smugglers leverage the fact that juveniles are less likely to face criminal

22 (2017) of the Committee on the Rights of the Child on the General Principles regarding the human rights of children in the context of international migration (Joint General Comment No. 3); and Joint General Comment No. 4 (2017) of the Committee on the Protection of the Rights of All Migrant Workers and Members of Their Families and No. 23 (2017) of the Committee on the Rights of the Child on State obligations regarding the human rights of children in the context of international migration in countries of origin, transit, destination and return (Joint General Comment No. 4). The two General Comments are available at www.ohchr. org/EN/NewsEvents/Pages/DisplayNews.aspx?NewsID=22408\&LangID=E.

22 See Committee on the Rights of the Child, The Rights of all Children in the Context of International Migration, Background Paper (August 2012), available at www.ohchr.org/Documents/HRBodies/CRC/Discussions/2012/2012DGDBackgr oundPaper.pdf.

${ }_{23}$ The International Labour Organization (ILO) provides estimates of people trafficked or in forced labour. In 2016, the ILO estimates 21 million trafficked people and children $(<18)$ represent 26 per cent (5.5 million). See ILO, Statistics on Forced Labour, Modern Slavery and Human Trafficking (2016), available at www. ilo.org/global/topics/forced-labour/policy-areas/statistics/lang--en/index.htm. 
prosecution. ${ }^{24}$ Not all migrant children are innocent. Not all move without agency and intent.

As Jacqueline Bhabha notes, it was not until the 1990s that either policy-makers or scholars paid much attention at all to the drivers of child migration. ${ }^{25}$ Nor was any attempt made to address the obvious and unique vulnerabilities of children travelling and living as migrants in host countries. While children living out of home care have suffered and continue to suffer abuse and deprivation all around the world, the focus of child welfare initiatives until very recently has been on children who are citizens of a state. Bhabha points to two factors that have operated as agents of change. The first is the global rise in the number of children on the move as solo migrants, travelling either alone or separated from responsible family members. She argues that the phenomenon has resulted in conflicting responses to children on the move. The vulnerability of unaccompanied or separated child migrants to human rights abuse has elicited sympathetic responses. Yet, real or imagined threats posed by young migrants with lived experience of violence and lawlessness have prompted punitive measures.

The second factor that has led to changes in attitude towards child migrants is legal. As we explore in Part II of this book, recent decades have seen a virtual explosion in international, regional and domestic laws and policies relevant to child migrants. These initiatives are recent but, sadly, have not necessarily ensured either uniformity in state practice nor uniformly sympathetic responses to young people on the move. The least that can be said is that migrant children are now included on the agenda of law-makers around the world.

Global developments in law and policy reflect a growing awareness of diversity in both the reasons children move across borders and the

24 Many nations do not criminally prosecute juveniles engaged in human smuggling. In the United States, the federal statutes require a transfer to the state for juvenile delinquency prosecution unless the state declines to prosecute. 18 USC s. 5032. Federal prosecutions of juveniles using the alien smuggling statute are very rare. In Arizona, juveniles are being prosecuted under a state delinquency statute. See E.S. Eaton and D. Gonzalez, 'Should young teens face trial as adults for aiding Mexican drug cartels?', Arizona Republic (Phoenix), 14 August 2016. Australia similarly does not prosecute young people engaged in smuggling if they are under the age of 18. See E. McKenzie, Prosecution of Juveniles or People Smuggling Offences, Practice Group Instruction No. 1, Human Exploitation and Border Protection (CDPP, 30 October 2014), p. 1. For a discussion of the US consideration of children with a criminal history, see also Farrin Anello, Chapter 22.

25 See J. Bhabha, Child Migration and Human Rights in a Global Age (Princeton University Press, 2014). 
situations they face. Academics have at last begun the task of analysing and deconstructing this complexity. ${ }^{26}$ Our aim is to complement this work, focusing on issues around the protection of migrant children. The range of scholars who have joined us in this venture stand testament to the growing interest within the academy in these issues. While many of the contributors in this book are legal scholars, almost all are actively engaged in direct advocacy or policy development. We are joined also by scholars from non-legal disciplines and by human rights workers. Our joint concern is to create a collection of chapters that will foster greater understanding of how and why children are on the move. Together we explore ways in which laws, policies and practices can or should operate to protect and nurture young migrants. Providing a broad survey of developments throughout the world, the chapters in this collection build a foundation for assessment and improvement in the rather chaotic and haphazard way in which states react to large movements of children.

Today, there are a multitude of legal schemes that intersect and press upon the lives of migrant children. Yet few nations, if any, have fully integrated norms of child welfare law into their migration laws and policies. Too often, immigration enforcement trumps the values and systems designed to promote the welfare of children. The universal notion that children's best interests should predominate is often not acknowledged at all in immigration adjudication. ${ }^{27}$ Migration systems need both greater substantive and procedural coherence to protect children on the move, even as they acknowledge the sovereignty and security concerns of host states.

In this introductory chapter we identify themes that will be carried throughout the book. We begin in section 2 with a discussion of the human rights challenges presented by children on the move, posing questions that our contributors will address as they build on the themes we identify. This is followed by an examination of obstacles that have been created to recognizing child migrants as rights bearers. After setting out in section 4 a brief outline of the book's structure, the chapter concludes with some comments on global initiatives that have been made to address the challenges associated with mass migration, on the one hand, and of forced movement of refugees on the other. We will argue that the uncertainty and

26 See, in particular, J. Bhabha, D. Senovilla Hernandez and J. Kanics (eds), Handbook on Migration and Childhood (Edward Elgar Publishing, 2018).

27 See discussion of the best interest standard in the UN Joint Committee Report No. 4, para. [11] (liberty and family life protection), paras. [14]-[15] (protections in proceedings and in tribunal determinations), para. [34] (assessing benefit of reunification with family), and para. [65] (in developing bilateral agreements). 
risks facing the world in the new millennium certainly constitute problems - but they also offer opportunities for positive change.

\section{MIGRATION AND CHILDHOOD: CHALLENGES AND QUESTIONS}

Four foundational principles inform our discussion of how states should respond to children on the move. The first is that childhood is unique in that the status of being a child is transitory and (absent disabilities) the capacities of children evolve as children age. Second, it follows that children require special protection and assistance, most particularly in their younger and adolescent years, if they are to develop and thrive. The third point is that procedural accommodations should be made for children in recognition of the physical and cognitive stages of their development. The fourth and final principle both flows from and unites the three that precede it. It is that the treatment of child migrants matters because it has long-term consequences, both for the children themselves and for their host communities. It is a truth too frequently demonstrated that the abuse of children affects how they develop and grow. Damaged children too frequently become damaged (and even potentially dangerous) adults. Conversely, making adequate provision for the protection of young ones displaced from hearth and home can lead to the enrichment not just of the young people themselves but also of the societies into which they are received. In what follows we will address each of these principles in turn.

\subsection{The Unique Status of Childhood: But Who Is a Child?}

By definition, the status of child is not static: childhood is a temporary condition that, for most, ceases with the passage of time. In many cultures, the attainment of a certain chronological age is set as the marker for transition into adulthood. Article 1 of the Convention on the Rights of the Child $^{28}$ (the most subscribed of all the UN Conventions other than the UN Charter itself) defines children as persons aged less than 18 years. However, this provision acknowledges that state laws may provide for majority to be attained earlier. It recognizes that concepts of childhood vary across cultures and legal regimes. For example, the United States defines majority age as 18 years for many purposes. However, for family

28 Convention on the Rights of the Child, adopted 20 November 1989, 1577 UNTS 3 (entered into force 2 September 1990) (CRC). 
reunification in migration law the age of 21 is used, unless the child has married: ${ }^{29}$ a valid marriage ends legal childhood regardless of a person's actual chronological age. ${ }^{30}$ In some countries, childhood is bounded by physical development such as the attainment of puberty or special rites of passage. Age may not be marked by the celebration of birthdays at all. ${ }^{31}$

In many countries, the determination of age in a child migrant will trigger a suite of procedural and substantive rights. But how accurate are the age determination processes used in migration processes in developed countries playing host to child migrants? In Chapter 17, Kenny and Loughry show that the mechanisms adopted by countries to determine chronological age can be intrusive, intrinsically harmful and not particularly accurate. Receiving nations can adopt sharp line definitions of childhood that do not comport with cultural or developmental reality. So we ask: if the aim of accommodating laws and procedures is to address vulnerability, should physical age alone be determinant of rights in young migrants? ${ }^{32}$

Cross-cultural expectations complicate all migration law but are particularly harmful when assumptions about agency and vulnerability interfere with acknowledging the needs of young people. In some cultures and communities of origin, adolescents may have greater agency and adult responsibilities than is the case in the countries to which the children

29 Thronson has highlighted the essential problem that statutory law requires pages to define who is a "child'. He notes: "not all children are "children" for immigration purposes. Under immigration law, a child is recognized as a "child" only if she meets the criteria of a "particularly exhaustive" statutory definition'. See David Thronson 'Entering the Mainstream: Making Children Matter in Immigration Law' (2010) 38 Fordham Urban Law Journal 393, at 397. The US Immigration and Nationality Act, s. 101(b) (fundamental definition of 'child') contains four different ages that define childhood. Adoptions must occur before 16 in most cases; step-child relationships must form before the age of 18; marriage ends childhood; and all other children are under 21 years of age. The statute devotes over 1,500 words to defining who is a child. Independently, the term 'unaccompanied alien minor' is found in the Trafficking Victims Reauthorization Act 2008, defining an unaccompanied child as under 18 at time of apprehension by the government at the US border. See TVPRA, 6 USC s. 279(g). See www.law. cornell.edu/uscode/text/6/279.

30 This is the case in many countries. In the United States, see, e.g., 8 USC s. 1101(b).

31 See T. Smith and L. Brownlees, Age Assessment Practices: A Literature Review and Annotated Bibliography, UNICEF Discussion Paper (2010), available at www.unicef.org/protection/Age_Assessment_Practices_2010.pdf.

32 Similar concerns about age assessments are expressed in the UN Joint Committee General Comment No. 4, above n. 21, paras. [3]-[4]. 
migrate. Imposing infantilizing restraints upon such youth may be disproportionately restrictive and even counter-productive. For example, both of the editors have encountered 16-year-old migrants, regarded squarely as children in US and Australian cultures respectively, who were already parents to children of their own by the time of their migration. ${ }^{33}$

Closely related to the physical age of a child and the child's cultural expectations of maturity is the fact that a child's mental and emotional capacity may vary over time and with experience. For some, past experiences of trauma or displacement may have impeded their mental and physical development such that chronological age is an inappropriate determinant of capacity. Legal systems need to be flexible and adapt to the reality of the needs of the young person. In all societies children are recognized as having abilities that evolve over time as the child grows and develops. This basic fact holds obvious significance for migrant children. The transient nature of childhood increases the likelihood that young people can experience the force of migration law in different ways, affecting both the substantive and procedural rights of an individual. In some instances, 'aging out' of childhood can be the difference between the right to remain in a host country and becoming susceptible to removal and return to a country of origin.

The administration of migration laws may require bright-line tests in some instances. Problematically, however, rigid rules based on chronological age can create perverse incentives for children to migrate before attaining majority. Such rules can also result in unfair or harsh treatment for children who have just crossed the line into a putative maturity. It will be our argument that a better approach is to adopt a more holistic assessment of need and vulnerability in young migrants that is not based solely on chronological age - even where this can be determined with any certainty. Precedents can be found in practices used to protect people with diminished capacity. We will argue that adjudication models should be built and managed such that the subject of the adjudication, the migrant child, is paramount. Our contributors are not the first to posit that fun-

33 Further complicating the legal treatment of these young parents is that their children may not qualify for the same benefits or legal treatment they receive if the child is also in need of protection. In the United States, birth in the territory confers citizenship on the child but the parent has no right to immigrate through this child's citizenship until the child is over 21 and only if the parent is not barred by previous law violations or grounds of inadmissibility. For an article discussing birthright citizenship see P. Weil, 'From Conditional to Secured and Sovereign: The New Strategic Link Between the Citizen and the Nation-State in a Globalized World' (2011) 9 International Journal of Constitutional Law 615. 
damental fairness for children cannot be achieved in systems designed for the adjudication of adult claims for protection. ${ }^{34}$ One size does not fit all.

\subsection{Migrant Children Need Substantive Protection and Care}

A migrant's status as a minor child does not confer any inherent right to enter or remain in a foreign country. ${ }^{35}$ It will be our argument, however, that states should respond to the presence of children in migratory flows by moderating the otherwise damaging and punitive effects of domestic immigration laws. In Chapter 4, Crock and Martin argue that international law has now developed to the point where it is possible to assert that states are obliged to extend special protections to children presenting as humanitarian migrants, because of their status as children. Put another way, child migrants are children first and, as such, deserve special treatment, including being afforded the immediate and temporary protection of the state. Any child who articulates relevant fears or who a government is aware is at risk due to war, natural disaster, or great economic and civil instability should be offered some form of stable and temporary protection. While the length and rights that attach to the sojourners' respite may vary, we believe that international law and existing regional and national legal regimes require states to offer children a safe and secure opportunity to seek protection from refoulement or return to danger.

These obligations should mean that states never submit children to interdiction and turn-back operations without first determining that these actions can be done without harming children. ${ }^{36}$ The same principles should apply to the transfer of asylum-seeking children to processing facilities in third countries where the security and basic human rights of the children could be at risk.

Part III of the book pursues issues around the substantive protection of migrant children in the domestic laws of countries that play host to these young people. It is here that we see examples of both good and bad practice

34 See, e.g., J. Bhabha and W. Young, 'Not Adults in Miniature: Unaccompanied Child Asylum Seekers and the New US Guidelines' (1999) 11 International Journal of Refugee Law 87.

35 See V. Chétail, 'The Transnational Movement of Persons under General International Law: Mapping the Customary Law Foundations of International Migration Law' in V. Chétail and C. Bauloz (eds), Research Handbook on International Law and Migration (Edward Elgar Publishing, 2014), p. 27 ff.

36 See, e.g., Human Rights Watch, Closed Doors: Mexico's Failure to Protect Central American Refugee and Migrant Children (2016), available at www.hrw.org/ sites/default/files/report_pdf/mexico0316web_0.pdf. 
in the jurisprudence created in the application of the Refugee Convention and of other relevant systems of human rights law. Contributors from Europe, North America and Oceania explore questions such as: How should children's claims for protection under the Refugee Convention be adjudicated and how should domestic legal regimes adapt to the special context of a child making a claim? Do children experience persecution in ways that are unique to childhood? When do children constitute a 'particular social group' for the purposes of invoking international protection from harm?

It is a fundamental tenet of child welfare in most developed countries that the state must provide children with the essentials of life, including adequate housing, food and access to education. While not every nation has the capacity to provide for the needs of all children, too often migrant children are seen and treated as exceptions to the general rule, even where resources are not an issue. Legal systems can ignore the needs of these children, creating impoverishment and neglect - a second class childhood for the foreign born.

It is beyond the scope of this book to discuss issues around the integration of migrant children into receiving nations. However, we will address immediate problems and concerns with the treatment of children apprehended upon arrival or identified in the course of enforcement or deportation operations. Too often governments detain migrant children and justify the detention as a means of protecting the children in question. The use and misuse of incarceration for migrant youth is a matter of global concern that has become the subject of considerable international and domestic jurisprudence and a vast body of literature in the fields of medicine, law and social science. The recent Joint General Comments from the UN Committee on the Rights of the Child (UNCRC) and the Committee on the Rights of Migrant Workers reject the use of detention for children as part of migration control. ${ }^{37}$ Research shows that when used, detention disproportionately harms the migrant child's psychosocial development and can leave children with a sense of abandonment and a lasting mistrust of authority. It can also compromise their ability to adequately prepare and present claims for protection. ${ }^{38}$

Because most youth on the move are treated as migrants first rather than as children, legal regimes around the world often lack some of the basic protections found in child welfare systems designed to promote the

37 UN Joint General Comment No. 4, above n. 21, paras. [5]-[10]. Detention should be brief and only as a last resort. Ibid.

38 These issues are discussed in Part V of the book. 
'best interests of the child'. In many countries, immigration processes bypass child welfare systems, relying instead on arrangements that either 'warehouse' migrant children or outsource the care and protection to border enforcement agencies. What does respecting the 'best interests of the child' require in these circumstances? Can detention ever be justified or seen as necessary for child migrants?

\subsection{Children Require Procedural Assistance}

If it is accepted that children have evolving capacities, there should be little contest that children require competent adult assistance if they are to adequately navigate complex legal systems. ${ }^{39}$ Again, in most developed nations, if a citizen child is the subject of a legal proceeding, he or she is provided with a skilled guardian and/or legal advocate. Too often, the same rights are not afforded to children in immigration processes. Our own research and experience show that without adequate interim care and skilled advocacy, child migrants are much less able to petition successfully for protection. Children need guidance in telling their stories to tribunals or decision-makers. Preliminary studies in the United States indicate that a child trying to secure protection in the immigration court without counsel is more than 84 per cent likely to fail. Conversely, children assisted by competent legal counsel obtain a form of relief in nearly 78 per cent of cases. ${ }^{40}$ These statistics align roughly with the findings of Australian researchers in the Seeking Asylum Alone project in 2004-2007. ${ }^{41}$

Almost all of the child migration systems discussed in this book permit a child to have legal assistance but none guarantees universal free representation. While chapters in this text will set out specific reasons why

39 See UN Joint General Comment No. 4, above n. 21, para. [16] expressly stating that children deserve free legal counsel: 'States should ensure standardized policies to guide authorities in offering free, quality legal advice and representation for migrant, asylum-seeking and refugee children, including equal access for unaccompanied and separated children in local authority care and undocumented children'.

40 Estimates based on published data available for cases begun in fiscal year 2014 and completed as of August 2016, available at http://trac.syr.edu/phptools/ immigration/juvenile/. See, e.g., Representation for Unaccompanied Children in Immigration Court (TRAC at Syracuse University, 2015), available at http:// trac.syr.edu/immigration/reports/371/, which finds a 14 -fold increase in positive outcomes for youth who are represented).

${ }_{41}$ See M. Crock, Seeking Asylum Alone: Unaccompanied and Separated Children and Refugee Protection: A Study of Laws, Policy and Practices in Australia (Themis Press, 2006), p. 125. 
legal counsel is necessary, a persistent obstacle to achieving this goal is the lack of transparency in the warehousing and processing of children's claims. Young migrants who are not mainstreamed into child welfare protection adjudication inevitably suffer. The burden of finding legal assistance often falls upon the child and specialist pro bono organizations.

What does it mean to incorporate the 'best interests of the child' standards into migration policy and processes? What are the costs and benefits of including this standard and what type of adjudication system is needed to fully implement the standard? When may a nation apply rapid adjudication models to children? Do the same standards of interdiction at sea, expulsion and return to countries of origin apply to children as to adult migrants? What are the essential protections that children need in rapid adjudication models? Should there ever be a blanket prohibition on deportation or expulsion of children?

We urge governments to evaluate child migration controls and adjudication against the same standards they would apply to child welfare adjudication regimes for their citizens. While foreign born children might not have the same substantive claims to financial support, there is no real justification for ignoring the lessons of child welfare law and process when designing and implementing child migration controls.

\subsection{Why Protection Matters for Child Migrants: The Long-term Consequences of Abuse}

Traumatic experiences resulting in cross-border displacement change lives in obvious ways. For children, however, the consequences of harmful early experiences can be truly profound, crippling a child's physical and/or psycho-social development. Migration and border processes are focused typically on national security and control. Insufficient attention is paid to designing systems that address the long-term consequences of the migration experience on children. Even where long-term status is not provided, experience all around the world suggests that asylum-seeking children are likely to spend significant time in the receiving country. ${ }^{42}$ Whatever their stage of development, the 'immigration years' are critical to a child's

42 The length of processing time varies greatly by country and whether complementary protection is available. Further, many states do not actively seek to remove youth until they reach the age of majority so it is likely many young people will spend their childhood in the receiving state. See, e.g., Catriona Jarvis and Syd Bolton in Chapter 12 discussing leave to remain for children under age 18. See Joint General Comment No. 4, above n. 21, para. [59] encouraging equality in access to education for migrant children. 
future. A failure to address the specific needs of these children can result in social costs for the receiving society as much as for the children themselves.

Ample evidence exists of the crippling effect on children of prolonged and punitive incarceration. ${ }^{43}$ Denial of access to appropriate care can produce education and emotional deficits that endure for the child's entire life. It will be our argument that states ultimately act against their own best interests when they ignore the short-term needs of migrant children, justifying the denial of care and protection because a child may not have a right to long-term resettlement or naturalization.

Of course, evidence also abounds that children can be remarkably resilient. Migrant children who suffer great hardships can grow up to become independent and successful adults who cherish their new home country and take full advantage of resettlement opportunities. This only happens, however, with thought and action on the part of receiving states. ${ }^{44}$ Childhood resilience should never be an excuse for affirmative neglect or abuse. Legal systems must have safeguards in place that allow for inspection, reporting, and correction of systems that are harming children. In this collection we address some of the most challenging tasks facing states playing host to children affected by war and conflict. These include the reception and rehabilitation of child soldiers and of children who are players themselves in trafficking and smuggling enterprises. When may a nation-state criminally prosecute a child migrant for violating border entrance laws or regulations? What are the consequences of criminalizing immigration violations for the juvenile? What strategies can be adopted to maximize the chance of rehabilitation of damaged young people while assuring the security of the host or resettlement communities?

43 See, e.g., UNHCR, Beyond Detention: Progress Report Mid 2016 (UNHCR, August 2016), available at www.unhcr.org/53aa929f6.pdf; see also Australian Human Rights Commission, A Last Resort? National Inquiry into Children in Immigration Detention (2004), available at www.humanrights.gov.au/human_rights/children_ detention_report/ind ex.html; I. Bronstein and P. Montgomery, 'Psychological Distress in Refugee Children: A Systematic Review' (2011) 14(1) Clinical Child and Family Psychological Review 44; M. Dudley, Z. Steel, S. Mares and L. Newman, 'Children and Young People in Immigration Detention' (2012) 25 Current Opinion in Psychiatry 285; and A. Lorek et al., 'The Mental and Physical Health Difficulties of Children Held Within a British Immigration Detention Centre: A Pilot Study' (2009) 33 Child Abuse and Neglect 573. See also J. Everitt, The Bitter Shore (Pan Macmillan, 2008), describing the impact of detention on a young child held in an Australian centre.

44 For a discussion of the Australian case see M. Crock (ed.), Creating Futures: Settling Children and Youth from Refugee Backgrounds (Federation Press, 2015). 


\section{OBSTACLES TO THE ACKNOWLEDGEMENT OF RIGHTS IN MIGRANT CHILDREN}

In spite of the growing interest in the phenomenon and plight of children on the move around the world, migration laws, policies and processes everywhere continue to pose particular problems for young people. In this section we examine some of the obstacles to the recognition of rights in child migrants that will recur as themes throughout the chapters that follow.

Like their adult counterparts, migrant children are being affected by the increasing restrictiveness of immigration regimes all around the world. If international travel has never been easier from a technological perspective, the legal constraints of visa regimes have made true freedom of movement the province of a relative minority of individuals from developed countries and/or from wealthy backgrounds. On the one hand, the administrative requirements attending lawful movement between countries have become increasingly complex. On the other, countries are resorting more frequently to erecting physical barriers in the fight against irregular migration. Such systems operate to both impede and endanger child migrants. Ironically, restrictive policies can create perverse incentives for irregular movement. For example, one could argue that the exponential increase in irregular child migrants from Central and South America to the United States is a product (at least in part) of restrictive policies that prevent parents living in the United States from sponsoring children as regular migrants..$^{45}$ Another example is the almost immediate spike in the number of asylum-seeker children travelling to Australia by boat following the

45 In 2014, UNHCR published a report based on over 400 interviews of migrant children and found that 49 per cent of El Salvadoran children had at least one parent in the United States; 27 per cent of Guatemala children; and 47 per cent of Honduran youth. See UNHCR, Children on the Run (2014), available at www.unhcr.org/en-us/children-on-the-run.html. One 2015 study of migrant children entering the United States estimates that children are unlikely to migrate alone unless a parent has migrated before the child. See K.M. Donato and B. Sisk, 'Children's Migration to the United States from Mexico and Central America: Evidence from the Mexican and Latin American Migration Projects' (2015) 3(1) Journal of Migration and Human Security 58 (data does not include Honduran children and is based on data prior to 2014 dramatic increase in Central American migration). The US government did create an expanded humanitarian parole programme allowing parents living within the United States to sponsor children for refugee processing in the country of origin. This programme is limited to children of people who are living in the United States with some form of status, which has greatly narrowed the programme. See www.uscis.gov/humanitarian/ humanitarian-parole/central-american-minors-cam-refugeeparole-program- 
institution of temporary protection visas in the late 1990s that removed family reunification rights. ${ }^{46}$

While respect for human rights and immigration restriction need not be mutually exclusive, the reality is that enforcement measures often lead to a diminished focus on human rights. Children die crossing seas and deserts in attempts to reach safety because regular migration routes are closed to them. Even where they manage to gain admission, migrant children are being detained and denied access to basic entitlements. Subscribing to the dualist approach to international law, ${ }^{47}$ Australia is one country in which domestic migration laws that are abusive of human rights prevail even when inconsistent with obligations assumed under international law. ${ }^{48}$ The United States similarly has not afforded full constitutional protection to non-citizens, especially to those apprehended upon arrival. ${ }^{49}$ United Nations High Commissioner for Refugees (UNHCR) research suggests that these countries are far from unique. ${ }^{50}$

Another, egregious, obstacle to the realization of human rights in migrant children is what we term 'deterrence theory'. ${ }^{51}$ The justification given so often for punitive and restrictive immigration control measures

information-conditionally-approved-applicants. This programme is discussed in Chapter 24 by pamela goldberg.

46 See Crock, Seeking Asylum Alone, above n. 41, at 38-9.

47 See G. Triggs, International Law: Contemporary Principles and Practices (LexisNexis Butterworths, 2006), pp. 105 para. [3.4], 142-3 para. [3.65].

48 See, e.g., H. Charlesworth, M. Chiam, D. Hovell and G. Williams (eds), The Fluid State: International Law and National Legal Systems (Federation Press, 2005).

49 See the discussion of the 'plenary power doctrine' in M. Taylor and K. Johnson, 'Vast Hordes . . . Crowding in Upon Us: The Executive Branch's Response to Mass Migration and the Legacy of Chae Chan Ping' (2015) 68 Oklahoma Law Review 185; and K. Knop, 'Here and There: International Law in Domestic Courts' (2000) 32 New York University Journal of International Law and Politics 501.

$50 \quad$ See UNHCR, Beyond Detention, above n. 43.

51 See M. Crock, 'Of Relative Rights and Putative Children: Re-thinking the Critical Framework for the Protection of Refugee Children and Youth' (2013) 20 Australian Journal of International Law 33; and M. Crock and D. Ghezelbash, 'Do Loose Lips Bring Ships? The Role of Policy, Politics and Human Rights in Managing Unauthorised Boat Arrivals' (2010) 19 Griffith Law Review 238. See also RIL-R v. Johnson, 80 F Supp 3d 164 (DDC 20150) (District Court rejects deterrence as legitimate reason to detain mothers and children seeking asylum) and the US government told the Ninth Circuit Court of Appeals it was no longer arguing that detention was necessary for deterrence. See also Flores v. Lynch, 2016 US App. LEXIS 12439 (9th Cir., July 6, 2016, No. 15-56434). This decision reaffirms the obligation on US authorities to release children as soon as possible, including children apprehended with a parent. 
is that they are necessary to deter irregular migration. The theory finds extreme expression in assertions by politicians in Australia that the country's interdiction and offshore processing regime is necessary to save lives at sea. ${ }^{52}$ The politicians point to the fact that thousands of people have died trying to reach the country by boat, and that the restrictive policies have been effective in bringing the maritime people smuggling trade in Australia to a virtual halt. The policies have resulted in individuals recognized as Convention refugees spending years in remote, tropical detention centres, surrounded in the case of Papua New Guinea's Manus Island by a hostile local population. The policy has led to refugees dying from disease, suicide (including by self-immolation) and from interpersonal violence. Women and children have been raped and subjected to other gross human rights breaches. ${ }^{53}$ The embodied refugee children have been abused in the interests of saving the lives of putative children whose parents would otherwise have sent them on a risky path in search of a better life. ${ }^{54}$

Migrant children also face obstacles that are both legal and attitudinal. In what may be characterized as institutional blindness, children on the move have literally and figuratively slipped under relevant radars. An obvious manifestation of the invisibility of children in migration flows is the dearth of statistical information on how many children are on the move and why they migrate. ${ }^{55}$ Where children travel with parents or other responsible adults, young people are rarely seen as having rights independent of the family collective of which they are perceived to be part. The children's rights will be determined often by the rights of adults with whom they are associated by relationship or responsibility. When parents are arrested or excluded as irregular migrants or as security risks, their children will often suffer collateral damage in decisions made about adults' legal standing. Children can benefit from derivative status, for example, when parents or guardians are granted protection in asylum processes. However, a one-in-all-in approach can also disadvantage children if no separate consideration is given to a child's specific protection claims. ${ }^{56}$ The global rise in the number of children traveling as solo migrants has increased attention on the fact that children can experience persecution and disadvantage in unique ways. While examples of good practice in the

52 See M. Gleeson Offshore: Behind the Wire on Manus and Nauru (Newsouth Press, 2016), ch. 1.

53 See ibid. and the 'incident reports' published by the Guardian Australia newspaper, at www.theguardian.com/news/series/nauru-files.

54 See Crock, 'Of Relative Rights and Putative Children', above n. 51.

55 See UNICEF, Uprooted, above n. 11.

56 See further discussion of remedies for children in David Thronson, Chapter 13. 
interpretation of international and domestic laws can now be identified, this remains an area where jurisprudence and practical experience are somewhat impoverished. ${ }^{57}$

The rightlessness of children relative to responsible adults can also be manifest in an imbalance between parents and children in family reunification laws and policies. This is an area where the law can tend to commodify children in the sense that migrating parents are seen as having rights to live and travel with their offspring. Conversely, national laws rarely confer equal rights on migrant children to sponsor their parents. Rather, the child's right to family unity is commonly qualified by conditions requiring parents to meet economic or stringent health criteria. ${ }^{58}$

Yet another obstacle to the realization of rights in migrant children has been the failure in international organizations to adopt a human rights focus in cooperative measures relating to migration control and transnational crime. As Ghezelbash documents, there are now a plethora of fora in which states meet to discuss these issues. ${ }^{59}$ However, the emphasis in these meetings is most often on measures to control immigration and on the punishment of offenders, rather than on the protection of migrant victims of abuse. In this book, a number of contributors address questions that have arisen in relation to international measures targeting human trafficking and the smuggling of migrants. In spite of the universal acceptance that children are rendered most vulnerable in these situations, here again domestic laws, policies and practices continue to emphasize state sovereignty over child protection.

The final problem we identify and discuss in this book is the pervasive failure in states to adopt a child rights focus in administrative procedures involving child migrants. Ironically, however widespread the failures in process, we will argue that this obstacle may well be the easiest one to remove. It is our hope that this book will increase awareness of the challenges facing both children and governments when young migrants engage with our immigration laws and policies. Through sharing the wisdom and experience of experts and practitioners, it is also our aspiration that the book itself may act as an agent for change within migration bureaucracies around the world.

57 See, e.g., Geraldine Sadoway, Chapter 15, discussing Canada; and Kate Bones and Timnah Baker, Chapter 14, comparing the United States and Australia.

58 Part III of the book contains chapters exploring the legal rights of children in Canada, Europe and the United Kingdom, the United States, Australia and Mexico.

59 See Daniel Ghezelbash, Chapter 21. 


\section{STRUCTURE OF THE BOOK}

The central argument we make in this book is that children on the move, and how they are treated, matter. We all have a stake in processes that experience suggests will end with young migrants settling and integrating into the communities of which we are part. If only for this reason, it is in everyone's interest to engage with the challenges posed by children travelling as forced or irregular migrants.

The book begins in Part I with two chapters in which the authors attempt to put numbers and faces on the children on the move around the world and the reasons they are migrating. The task is not an easy one, because statistical data disaggregated by age and gender across countries has never been created or collected in a uniform way. There are some regions of the world (South America and parts of Africa, for example) where information is sparse or non-existent. Malakooti's generalist chapter is paired with a case study by Martinez on Mexican and Central American children. ${ }^{60}$ Her chapter explores some of the historical and socio-political motivations of why children leave their homes and seek entry in the United States.

Part II of the book contains a series of chapters that provide the international and regional context for the more detailed consideration of the laws, policies and practices affecting children on the move in different parts of the world. The first block of three chapters in this part addresses aspects of international law. Chapter 4 by Crock and Martin has as its focus the international foundations that protect migrant children, and Chapter 5 by Crock and Yule focuses on the Convention on the Rights of the Child (CRC) and other human rights conventions, as well as children as subjects of international refugee law. ${ }^{61}$ In Chapter 6, Schloenhardt and Lelliot examine critical frameworks created to deal with human trafficking and the smuggling of migrants across borders. ${ }^{62}$

The second group of chapters in this Part takes us to the regional frameworks relevant to the protection of migrant children. Danisi reminds us in Chapter 7 that two systems of protection interact in Europe when a migrant child arrives in one of the EU Member States. ${ }^{63}$ Both acknowledge the importance of respecting the best interests of the child. First, the European Union has developed a normative framework grounded in the 1951 Refugee Convention and the CRC. This finds expression in the

60 See Arezo Malakooti, Chapter 2 and Isabel Martinez, Chapter 3.

61 See Mary Crock and Hannah Martin, Chapter 4 and Mary Crock and Phoebe Yule, Chapter 5.

62 See Andreas Schloenhardt and Joseph Lelliott, Chapter 6.

63 Carmelo Danisi (with Mary Crock), Chapter 7. 
fundamental rights (re)affirmed in the Charter of Fundamental Rights of the EU (CFR) ${ }^{64}$ and the Treaty on the European Union itself. Second, EU Regulations and Directives in the field of asylum and migration must conform with minimum standards of protection enshrined in the European Convention on Human Rights (ECHR) as interpreted by the European Court of Human Rights (ECtHR). If the European systems and laws are well known, the two chapters that follow provide insights into regional human rights frameworks that have attracted less academic attention. In Chapter 8, human rights workers Petros and Olusese join with Nairobi University's Professor Abuya to set out the elements of the African system, offering a case study of how unaccompanied child migrants are treated in Kenya. ${ }^{65}$ Holguin and Kumar explain in Chapter 9 the workings of the Organization of American States (OAS) and special instruments that should protect migrant children. ${ }^{66}$ They report on current litigation brought on behalf of Central American women and children challenging detention and expedited deportation procedures as violations of essential human rights guaranteed by the OAS instruments.

Part II. 2 complements these framework chapters with two case studies looking at protection issues surrounding children at work. In Chapter 10, Van Doore takes the discussion of initiatives targeting human trafficking into South East Asia. ${ }^{67}$ She argues against a simplistic characterization of Asian children at work as victims of trafficking, noting that cultural attitudes and economic necessity create an environment in which children can be expected to join the workforce at a young age. The search for remunerative employment can lead young adults to make reasoned decisions to cross borders. The second chapter in this series concerns young people moving for work within one of the world's most populous nations: China. Zou's more historical piece is included at Chapter 11 because of the scale of child migration within this country and the place China is assuming as a powerhouse economy in the world as it sheds its status as a developing country. ${ }^{68}$

64 Adopted in Strasbourg [2012] OJ C326/391. Article 51 of the CFR states that the Convention is addressed 'to the institutions, bodies, offices and agencies of the Union with due regard for the principle of subsidiarity and to the Member States only when they are implementing Union law'. See S Peers et al., The EU Charter of Fundamental Rights, A Commentary (Hart Publishing, 2014), p. 661.

65 See Agnes Olusese, Shamm Petros and Edwin Odhiambo Abuya, Chapter 8.

66 See Carlos Holguín and Kavita Kapur, Chapter 9.

67 See Kathryn Van Doore, Chapter 10.

68 See M Zou, Chapter 11. 
Part III of the book gathers experts from several nations to describe and examine the adequacy of domestic law and how nations are implementing legal schemes designed to protect migrant children and child asylum-seekers. In Chapter 12, Jarvis and Bolton begin by examining the UK and EU experience of offering complementary protection to some child migrants while not fully offering refugee protection. ${ }^{69}$ This chapter necessarily discusses the intersection of international and domestic laws as they protect children. In contrast, Thronson explains in Chapter 13 the reality faced by migrant children found within the United States or at its borders. There, domestic laws include a complex amalgam of federal and state child welfare measures. ${ }^{70}$

In Chapter 14, Baker and Bones expand our understanding by providing a comparative chapter on asylum law for children in Australian and US law. ${ }^{71}$ Their assessment illuminates the critical role of adjudication and charts the development of common law jurisprudence on asylum protections for children. In Chapter 15, Sadoway describes the procedure and substantive law that is used to adjudicate children's asylum claims in Canada. She notes the need to improve the role of guardians and to adjust the adjudication models to the needs of vulnerable children. ${ }^{72}$

In Part IV of the book we study the interaction of migrant children with protection processes. Kenny and Loughry argue in Chapter 16 that techniques that prioritize the identification of physical markers of age often involve harmful and intrusive procedures such as bone scans, yet producing results of doubtful accuracy. ${ }^{73}$ Benson and Thomas in Chapter 17 and Taylor in Chapter 18 provide detailed country-specific chapters on the procedural entitlements and treatment of unaccompanied children, including the right to counsel. ${ }^{74}$

Part V of the book contains three quite diverse chapters on children and immigration detention. It begins in Chapter 19 with Neuman's piece on the UN Human Rights Committee's General Comment on detention that he helped to draft when serving as a member of that Committee. ${ }^{75}$ This body has oversight of the International Covenant on Civil and Political Rights (ICCPR). In a thought-provoking chapter, Neuman argues that if the best interests of the child are to be respected, detention may sometimes

\footnotetext{
69 See Catriona Jarvis and Syd Bolton, Chapter 12.

70 See David Thronson, Chapter 13.

71 See Kate Bones and Timnah Baker, Chapter 14

72 See Geraldine Sadoway, Chapter 15.

73 See Mary Anne Kenny and Maryanne Loughry, Chapter 16.

74 See Lenni B. Benson and Claire Thomas, Chapter 17 and Savitri Taylor, Chapter 18.

75 See Gerald Neuman, Chapter 19.
} 
be the best option, for example, for young migrants who would otherwise lack any form of care and protection. In Chapter 20, Triggs provides stark contrast material in her description of the at times gross abuses of children's rights that have occurred in detention centres across Australia, as well as in facilities run and funded by that country in Nauru and Papua New Guinea's Manus Island. ${ }^{76}$ Ghezelbash concludes in Chapter 21 by exploring the tendency in states to copy each other's laws and policies - often with disastrous consequences for migrant children. ${ }^{77}$ His chapter tracks the apparent transfer or borrowing of immigration detention laws and policies between Australia and the United States.

The book continues in Part VI with three chapters exploring different facets of child migrants and the interface between migration law and criminal law. In Chapter 22, Anello explores how the criminalization of immigration status or prosecution for criminal acts severely reduces or eliminates protections for child refugees and others. ${ }^{78}$ There follows a chapter examining the treatment at law and in practice of child soldiers. Writing from practical experience in South Sudan, in Chapter 23, Tyler and Whitman describe the problems inherent in the post-conflict (re-) integration of children who have been forced into war. ${ }^{79}$

The book concludes in Chapter 24 with a contribution by pamela goldberg on UNHCR's search for regional solutions in partnership with the US government to process (at point of origin or transit) the claims of migrant youth in Central America. ${ }^{80}$

In 2016, UNICEF articulated six goals and practical suggestions to improve the lives of child migrants and refugees that we think capture well the essence of the contributions made by the authors in this volume. ${ }^{81}$ These relate to the protection of children from exploitation and violence; the use of detention; family unity; access to education; the need for action on the underlying causes of large-scale movements; and measures to combat xenophobia, discrimination and marginalization in countries of transit and destination. ${ }^{82}$ While our various contributors write as

76 See Gillian Triggs, Chapter 20.

77 See Daniel Ghezelbash, Chapter 21.

78 See Farrin Anello, Chapter 22.

79 See Kasey Tyler and Shelly Whitman, Chapter 23.

80 See pamela goldberg, Chapter 24.

81 UNICEF, Uprooted, above n. 11.

82 These goals and suggestions find expression in the principles for the 
individuals and no claim is made that they adopt the views of any other contributor, there is a unity in the messages conveyed. This is found in the view that children deserve protection, but also respect insofar as they have both a right to be heard and a right to exercise agency to the extent that their capacities allow. If nations continue to ignore the special vulnerabilities and characteristics of child migrants, they will fail to meet the protection standards demanded by international and domestic law.

No single volume can suffice to capture the complex and rapidly changing legal treatment of child migrants. We trust that this book will help to illuminate some common concerns, failures and shortcomings but that it will also identify examples of best practice as we adapt to the reality of child migration. For us, the evidence and arguments presented by our contributors compel action and reform. We should strive for uniform definitions and measures that enable us to better understand the reality and challenges of child migration. Countries everywhere need to integrate the essentials of child welfare and child protection into border control and immigration controls. Mechanisms for adjudication and assessment of children's claims should be devised and run so as to protect the fundamental rights of children as children - and to do no harm.

As we stand on the brink of achieving a new global consensus on migrants and refugees, it is well to recall that migrant children everywhere are part of our future. Critically, the fulfilment of their potential is in our hands.

treatment of migrant children enshrined in the more recent Joint General Comments issued by the Committee on the Rights of the Child and the Migrant Workers Committee. See the two Joint General Comments, above n. 21. 